\title{
AGREGAÇÃO FAMILIAR NA PRESSÃO ARTERIAL E NA COMPOSIÇÃO CORPORAL DE FAMÍLIAS NUCLEARES PORTUGUESAS
}

\author{
FAMILIAL AGGREGATION IN BLOOD PRESSURE AND BODY COMPOSITION IN \\ PORTUGUESE NUCLEAR FAMILIES
}

\begin{abstract}
RESUMO
O objetivo deste estudo foi (1) verificar a presença indireta de transmissão vertical de fatores genéticos entre progenitores e descendentes na pressão arterial (PA) e na composição corporal (CC), e (2) estimar a contribuição dos fatores genéticos que são responsáveis pela variabilidade nos valores da PA e em diferentes fenótipos da CC em termos populacionais. A amostra foi constituída por 367 indivíduos (164 progenitores $-41 \pm 4,6$ anos e 203 descendentes - 13,2 \pm 3 anos) pertencentes a 107 famílias nucleares participantes do projeto FAMÍLIAS ACTIVAS, provenientes de diferentes regiões do Norte de Portugal (36 de Vouzela, 36 de Esposende, 25 de Vila Nova de Paiva e 10 de Vila Nova de Famalicão). A PA foi mensurada com um aparelho digital automático da marca Omron ${ }^{\circledR}$ modelo M6 (HEM-7001-E). Os fenótipos da CC foram avaliados com um aparelho de impedância bioelétrica da marca Tanita ${ }^{\circledR}$ modelo BC-418 (Tanita Corp., Tokyo, Japan). 0 software PEDSTATS foi utilizado para verificar a estrutura de cada família e analisar o comportamento genérico das variáveis entre os diferentes membros da família. Os módulos FCOR e ASSOC, do software de Epidemiologia Genética S.A.G.E. versão 5.3, foram utilizados para o calcular os coeficientes de correlação $(r)$ e as estimativas de heritabilidade $\left(h^{2}\right)$ dos fenótipos. Foi adotado um nível de significância de 0,05 . Os resultados evidenciaram uma forte agregação familiar entre os diferentes membros da família, tanto para a PA sistólica (PAS) $(0,01 \leq r \leq 0,35)$, quanto para a PA diastólica (PAD) $(0,24 \leq$ $r \leq 0,50)$ e os diferentes fenótipos da CC $(-0,15 \leq r \leq 0,65)$. As estimativas de $\mathrm{h}^{2}$ encontradas evidenciaram que os fatores genéticos explicaram, de maneira significativa, cerca de $43 \%$ da PAS, $49 \%$ da PAD e de 35 a $46 \%$ da variação total dos diferentes fenótipos da CC. Conclui-se que (1) existe uma forte AgF na PA e na CC nesta amostra de famílias nucleares portuguesas e que (2) os fatores genéticos são responsáveis por uma quantia moderada na variação total dos valores da $\mathrm{PA}$ e da CC em termos populacionais.
\end{abstract}

Palavras-chave: Epidemiologia Genética; Genética Quantitativa; Heritabilidade; Fatores de Risco; Doenças Cardiovasculares.

\section{ABSTRACT}

The aims of this study were (1) to verify the indirect presence of vertical transmission of genetic factors between parents and children in blood pressure (BP) and body composition (BC), and (2) identify the influence of genetic factors in the variability of BP and BC. Sample size comprises 367 subjects (164 parents: $41 \pm 4.6$ years old and 203 children of $13.2 \pm 3$ years old) from 107 nuclear families participating in the project "FAMÍLIAS ACTIVAS"; they proceed from different regions of North of Portugal (36 from Vouzela, 36 from Esposende, 25 from Vila Nova de Paiva and 10 from Vila Nova de Famalicão). BP was measured with an automatic digital device, Omron ${ }^{\circledast}$ model M6 (HEM-7001-E). BC phenotypes were assessed with a bioelectric impedance device from Tanita ${ }^{\circledR}$ model BC-418 (Tanita Corp., Tokyo, Japan). PEDSTATS was used to verify the structure of each family and to analyze the generic behavior of the variables in family members. FCOR and ASSOC modules, from Genetic Epidemiology S.A.G.E. 5.3 software, were use to calculate correlations $(r)$ and the heritability $\left(h^{2}\right)$ of different phenotypes. Significant level was set at 0.05. Main results evidenced an important familial aggregation between family members for systolic BP (SBP) $(0.01 \leq r \leq 0.35)$, and diastolic BP (DBP) $(0.24 \leq r \leq 0.50)$ the same occurred for BC phenotypes $(-0.15 \leq r \leq 0.65)$. Genetic factors contributed to $43 \%$ of the SBP and $49 \%$ of DBP variation; the same occurred for $\mathrm{BC}$ phenotypes ranging from 35 to $46 \%$ of the total variation. The conclusions were that (1) a strong familial aggregation exists in the BP and the BC in this sample of portuguese nuclear families and that (2) genetic factors play important role in these phenotypes.

Key words: Genetic Epidemiologic; Genetic Quantitative; Heritability; Risk Factors; Cardiovascular Diseases.

1 Mestrado em Ciências do Desporto. Faculdade de Desporto, Universidade do Porto - Porto, Portugal (2007).

Orientador: Prof. Dr. José António Ribeiro Maia 